\title{
Resilience of Willow Stems After Release From Intense Elk Browsing
}

\author{
Bruce W. Baker, ${ }^{1}$ H. Raul Peinetti, ${ }^{2}$ and Michael B. Coughenour ${ }^{3}$ \\ Authors are ${ }^{1}$ Research Wildlife Biologist, US Geological Survey, Fort Collins Science Center, Fort Collins, CO 80526-8118; \\ ${ }^{2}$ Professor, Facultad de Agronomia, Universidad Nacional de La Pampa, cc 300, CP 3600, Santa Rosa, Argentina; and \\ ${ }^{3}$ Senior Scientist, Natural Resource Ecology Laboratory, Colorado State University, Fort Collins, CO 80523-1499.
}

\begin{abstract}
The resilience of willow (Salix monticola Bebb, Salix geyeriana Anderss., Salix planifolia Pursh) stems released from intense elk (Cervus elaphus) browsing in Rocky Mountain National Park, Colorado, was quantified in 1998 with a retrospective study that compared biomass, number, and length of segments on willow stems located inside (protected) and outside (browsed) elk exclosures. Segment biomass increased each year after protection by about 3-12 $\mathrm{g} \mathrm{year}^{-1}$ on browsed stems and 10-27 g year ${ }^{-1}$ on protected stems. The number of segments on stems was similar for browsed and protected stems in the first 2 years after exclusion but differed in the next 3 years, when they increased exponentially on protected stems. Nearly $80 \%$ of segments on browsed stems were $<5 \mathrm{~cm}$ in length in 1994-1997, which caused stems to develop a short-hedged morphology. Protected stems had more long segments and fewer short segments than browsed stems for the first 3 years, but then increased their number of short segments as stems became tall and bushy. Thus, evidence suggests short-hedged willow stems are highly resilient and can rapidly recover height and vigor after protection from intense elk browsing.
\end{abstract}

\section{Resumen}

Mediante un estudio retrospectivo se cuantificó la resiliencia de tallos de sauce (Salix monticola, S. geyeriana, S. planifolia) al intenso ramoneo de ciervos (Cervus elaphus), en el Parque Nacional de las Montañas Rocallosas, Colorado, USA, en el año 1998. Se comparo la biomasa, numero y longitud de segmentos de tallos de sauces localizados dentro (protegidos) y fuera de clausuras (áreas de exclusión de ciervos, establecidas en 1994), denominados ramoneados. La biomasa de los segmentos incrementó después de la protección, aproximadamente $3-12 \mathrm{~g}$ año $^{-1}$ en tallos ramoneados y $10-27 \mathrm{~g}_{\text {año }}^{-1}$ en tallos protegidos. En los primeros dos años de exclusión el número de segmentos fue similar en los tallos ramoneados y protegidos. En los tres años siguientes fue mayor en los protegidos debido al incremento exponencial de los mismos. Aproximadamente el $80 \%$ de los segmentos de los tallos ramoneados generados entre 1994 y 1997 tenían una longitud inferior a $5 \mathrm{~cm}$, lo cual determinó que estos tallos desarrollaran un porte bajo. En los primeros tres años, los tallos protegidos tuvieron más segmentos largos y menos segmentos cortos que los ramoneados. En los años siguientes el número de segmentos cortos aumentó, conforme los tallos protegidos incrementaron su altura y ramificación. Los datos sugieren que los tallos de porte bajo sometidos a ramoneo intenso son altamente resilientes, ya que pueden recuperar su altura y vigor si son protegidos del ramoneo intenso de ciervos.

Key Words: alternative stable states, Cervus elaphus, herbivory, Rocky Mountain National Park, Salix, stem morphology

\section{INTRODUCTION}

Ecological resilience can be defined as the speed at which a system returns to a former pristine state after it has been perturbed and displaced into a degraded state (Suding et al. 2004). Stability of a new state in the absence of continued manipulation is evidence the system has moved to an alternative stable state (Beisner et al. 2003). Intense herbivory has created an alternative stable state if cessation of herbivory alone fails to restore pristine plant conditions (Laycock 1991). Thus, strong resilience of degraded plants after release from intense herbivory can indicate the absence of an alternative stable state and a positive direction toward restoration of pristine conditions.

Funding was provided by the US Geological Survey and the National Park Service. At the time of the research, Peinetti was a graduate student at the Natural Resource Ecology Laboratory, Colorado State University, Fort Collins, CO.

Correspondence: Bruce Baker, USGS-FORT, 2150 Centre Avenue, BIdg C, Fort Collins, C0 80526-8118. Email: bruce_baker@usgs.gov

Manuscript received 25 February 2005; manuscript accepted 7 July 2005.
Willow (Salix) communities dominated many riparian ecosystems before European settlement of North America. Many of these communities developed degraded conditions after intense herbivory by livestock and/or native ungulates, which can congregate near water and heavily browse willows (Belsky et al. 1999; Brookshire et al. 2002). The elimination of large predators has reduced predation risk in some riparian areas, which historically may have prevented intense browsing of willows by large herbivores (Laundre et al. 2001; Ripple and Beschta 2004). Thus, intense browsing can dramatically reduce the extent of willow communities and suppress the height of remaining stems.

Why are tall willow stems important to riparian ecosystems? Tall willows provide shade to streams and critical habitat for a diverse array of terrestrial and aquatic species, as well as energy dissipation and sediment retention during floods (Case and Kauffman 1997; Belsky et al. 1999). Tall willows can be necessary to beaver (Castor canadensis) as winter food and used for construction material in dams and lodges, which can greatly benefit wetland ecosystem processes (Baker and Hill 
2003). Willows can sprout new stems in proportion to the number cut by beaver (Kindschy 1985, 1989) and can benefit from beaver ponds that raise the water table and improve establishment and survival processes; thus, beaver and willows can be mutualists. This mutualism can be disrupted in heavily browsed environments when beaver cut tall willow stems and place regrowth within easy reach of herbivores (Baker 2003). The interaction of beaver and elk (Cervus elaphus) herbivory greatly reduced the height and standing crop of willow regrowth in Rocky Mountain National Park (RMNP), Colorado (Baker et al. 2005). Tall willow communities and beaver populations have both declined dramatically in RMNP where intense elk browsing has created short-hedged willow stems that are unsuitable to beaver (Peinetti et al. 2002; Baker et al. 2004). Are short-hedged willow stems resilient to cessation of elk browsing or are they in an alternative stable state that requires more than release from elk to recover tall willow stems?

In this article, we show how protection from elk browsing affected the morphology of severely hedged willow stems in RMNP. Specifically, we tested the null hypotheses that there were no differences within each of 5 segment years in the biomass, number, and length of stem segments sampled from the tallest stems within the tallest plant strata for 3 willow species (Salix monticola Bebb, Salix geyeriana Anderss., and Salix planifolia Pursh) located inside (protected) and outside (browsed) 4 elk exclosures.

\section{METHODS}

\section{Study Area}

Study sites were in Horseshoe Park (elevation $2600 \mathrm{~m}$ ), RMNP, a broad flat alluvial valley dominated by the 3 studied species of willows, birches (Betula spp.), grasses, and sedges. Formerly abundant, most beaver populations declined after about 1940. Declines were likely initiated by trapping but recovery has likely been precluded by reduction in willow height and biomass due to intense elk browsing (Baker et al. 2004; Baker et al. 2005). Elk were reintroduced to RMNP in 1913-1914 after nearly being extirpated by the late 1800s. Control efforts maintained the elk population at 500 until 1968 , when a policy of natural regulation altered management and elk increased to $\sim 3000$ by the late 1990s (Singer et al. 1998). Elk utilization of riparian willows (\% leaders browsed) averaged $\sim 85 \%$ annually in 1968-1992 (Zeigenfuss et al. 1999) as the elk population increased to 6 times its 1968 level (Lubow et al. 2002). Elk were the primary browsers of willows; mule deer (Odocoileus hemionus) use was very light and moose (Alces alces) were absent. The height of mature willow stems was $2-4 \mathrm{~m}$ in nearby areas of RMNP that received less elk use. Tall willow cover $(>2.0 \mathrm{~m})$ declined by $65 \%$ in Horseshoe Park in the last 50 years and short-hedged willows $(<1.5 \mathrm{~m})$ have dominated the study sites for several decades (Peinetti et al. 2002).

\section{Experimental Design}

We measured stem response on willow plants 4 years after cessation of intense elk browsing with a retrospective design. Biomass, number, and length of stem segments were compared for willows stems located inside (protected) and outside (browsed) 4 elk exclosures (treatment replicates; RMNP exclosures 3, 4, 5, and 6). Elk exclosures (3-m-tall net wire) were constructed in August-November 1994 after randomly locating adjacent paired $30 \times 46 \mathrm{~m}$ plots in a short-hedged willow community located in elk winter range and randomly selecting 1 plot for exclosure treatment and the other plot as a paired control left available to elk (Peinetti et al. 2001; Zeigenfuss et al. 2002). Previous studies of these plots found the water table was shallow and equally accessible to mature willows (Alstad et al. 1999), the depth to water table had no effect on plant response to elk browsing (Zeigenfuss et al. 2002), and soil texture and nitrogen availability were similar inside and outside elk exclosures 3 years after elk exclusion (Menezes et al. 2001). These multiple lines of evidence support the assumption that plants within paired plots grew in similar environments, although factors other than elk browsing likely influenced the morphology of specific stems.

Sampling procedures were constrained to include only taller willow stems in the target population because RMNP managers were interested in recovery of tall stems as a prerequisite for restoration of the historical beaver-willow community. To exclude shorter stems we arbitrarily determined the tallest size stratum in each of the 8 plots by measuring the height of the tallest willow in the plot (any of the 3 species) and multiplying this upper bound by 0.75 to determine the lower bound of the stratum. For each of the 3 willow species in the 8 plots we selected the plant that was nearest a random point and constrained by the strata bounds. On each plant we selected either the tallest stem or the stem that was nearest the random point, if there appeared to be $>1$ stem that was tallest.

\section{Stem Measures and Statistical Analysis}

We followed Dahl (1995) for all terms used to describe plant morphology except segment, which we defined as shown below. Shrubs like willow typically have multiple stems that are distinct at ground level. Shoot is a collective term for a young stem and leaves, or any young growing branch or twig. Shoots typically consist of repeated structural units called phytomers or metamers, which contain leaf nodes, internodes, and leaves. Shoots can be further defined as short shoots or long shoots, as we explain in the Discussion section. The tips of shoots are called leaders, which can be browsed by large herbivores. Willows exhibit a sympodial branching pattern with distinct bands around the entire stem that readily separate linear growth years (Alliende and Harper 1989). We defined the stem material between these bands as segments or segment years.

At the end of the 1998 growing season (late August), selected stems were cut and removed at ground level, their total length was measured, leaves and dead portions were removed, and the stem was cut and sorted into segment years (range 1983-1998). Stems were processed by beginning at leaders and working toward the base of stems to locate and cut bands and place the resulting segments into segment years or age cohorts; the number of cohorts was confirmed by counting the number of annual rings at the base of stems (Peinetti et al. 2001). In this retrospective design we were unable to measure stem material lost to shoot shedding (loss of short shoots as stems age) or herbivory and we did not estimate annual radial growth as a component of segment biomass. Segment length was measured and segments were placed into 1 of 3 arbitrary 
classes $(0-5,5-15$, and $>15 \mathrm{~cm})$ to compare proportional segment length among treatments and years. All stem segments were oven-dried at $65^{\circ} \mathrm{C}$ and weighed to compute biomass.

Segment biomass data were transformed to the log (biomass +1 ) scale to stabilize variances and analyzed separately for each segment year using split-plot analysis of covariance (ANCOVA) (SAS Institute 2000) (proc mixed; class block treatment species; model biomassafter $=$ treatment|species biomassbefore/ddfm $=$ satterth solution; random block treatment"block; lsmeans treat/pdiff cl;). Exclosures and paired adjacent plots were treated as whole plots (blocks) and species were treated as subplots, with a total of 23 degrees of freedom in the error terms (Satterthwaite method). The variance structure of the model assumes mutual independence with random block, whole-plot, and subplot effects. The variable "biomassbefore" was a covariate to account for differences in initial condition and was the sum of biomass values for segment years before the exclosures were constructed (segment years $\leq 1993$ ); the variable "biomassafter" was the biomass of a particular segment year after the exclosures were constructed. Segment number data were transformed and analyzed with the same procedures; number of segments before the exclosures were constructed (segment years $\leq 1993$ ) was the covariate. Segment length data were converted to proportions to relate differences among treatments and years symmetrically; proportions were transformed to the arcsine ( $\vee$ proportion) scale to normalize data. Transformed proportion data were analyzed in accordance with the same procedures, with the proportion of segments in each length class as the covariate (segment years $\leq 1993)$. Each length class and segment year combination $(n=15)$ was analyzed with a separate ANCOVA. Repeated measures analyses were not used for response variables because variance changed greatly across time and because explicit comparisons across time were of no interest.

\section{RESULTS}

\section{Segment Biomass}

Test results for treatment $\times$ species interactions for segment biomass by year were $P=0.813$ for $1994, P=0.158$ for 1995 , $P=0.463$ for $1996, P=0.218$ for 1997 , and $P=0.832$ for 1998. Thus, segment biomass results are reported for combined species because we found no evidence that treatment effect depended on willow species.

Segment biomass of willow stems inside exclosures rapidly increased following release from intense elk browsing (Fig. 1a). Biomass of protected stems increased by $20-30 \mathrm{~g} /$ year for the first 3 years (1994-1996), then by 10-20 g/year for the next 2 years (1997-1998). In contrast, biomass of browsed stems increased by only $5-10$ g/year in 1994-1997, likely because elk removed current annual growth during winter browsing. Segment biomass inside and outside exclosures did not differ in 1998, likely because we had removed stems for analysis before elk had returned to winter ranges. Taken together, these results suggest browsed stems at least partially compensated for biomass removed during the previous winter, but that a large amount of new growth was subsequently removed by elk during winter browsing. Most browsing occurred in November-April when elk densities in Horseshoe Park were a) Biomass

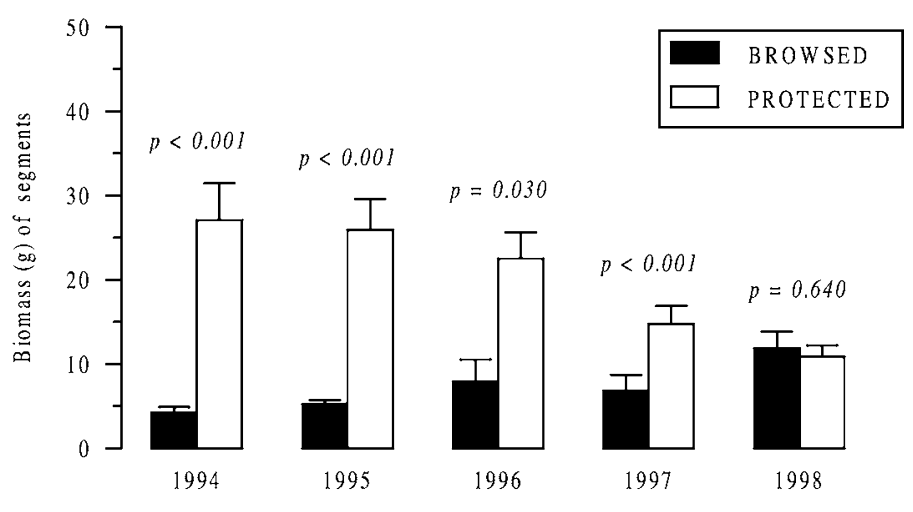

b) Number

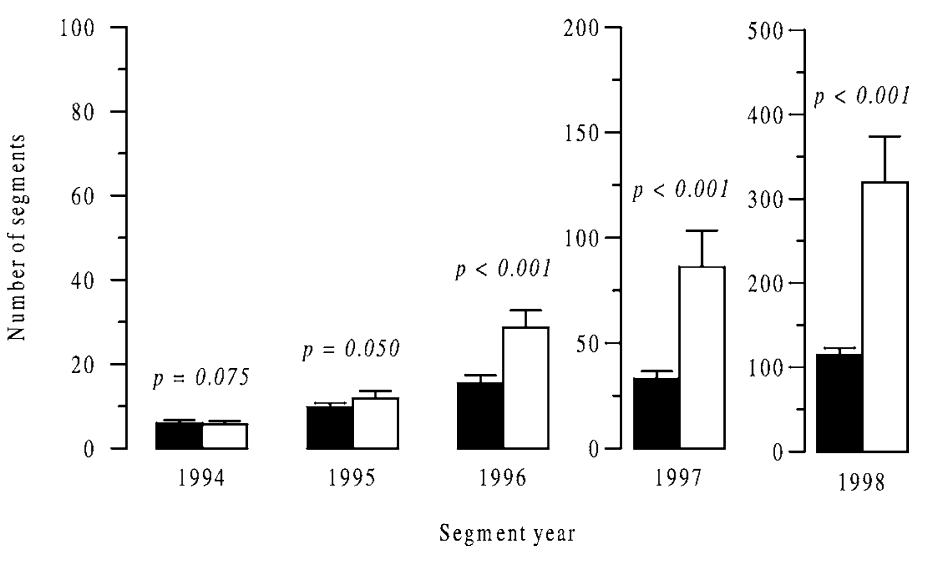

Figure 1. Comparisons (mean and standard error) of segment biomass (a) and segment number (b) on willow stems located outside (browsed) and inside (protected) elk exclosures $(n=4)$ in Rocky Mountain National Park, Colorado. Exclosures were constructed in fall 1994 and stems were sampled in late August 1998; thus, year 1998 represents segments that had not been browsed by elk during the 1998/1999 winter season. Probability values were based on transformed data (see Methods section).

30-64 elk km ${ }^{-2}$, although some browsing could occur in any month (Singer et al. 2002).

\section{Segment Number}

Test results for treatment $\times$ species interactions for segment number by year were $P=0.524$ for $1994, P=0.868$ for 1995 , $P=0.587$ for $1996, P=0.935$ for 1997 , and $P=0.823$ for 1998. Thus, segment number results are reported for combined species because we found no evidence that treatment effect depended on willow species.

The number of stem segments on browsed and protected stems were relatively similar for the first 2 years after protection from elk (1994, 1995), but then differed greatly in later years (1996-1998; Fig. 1b). Differences were greatest in 1997 and 1998, when protected stems developed a tremendous pulse of new segments.

\section{Segment Length and Stem Length}

Treatment $\times$ species interactions for segment length by class by year were not significantly different $(P>0.050)$ for 14 of 
a.



b. 1995
0
0
0
0
0
0
0
0
0
0
0
0
0
0
0
0
0
0
0
0
0
0
0

e.

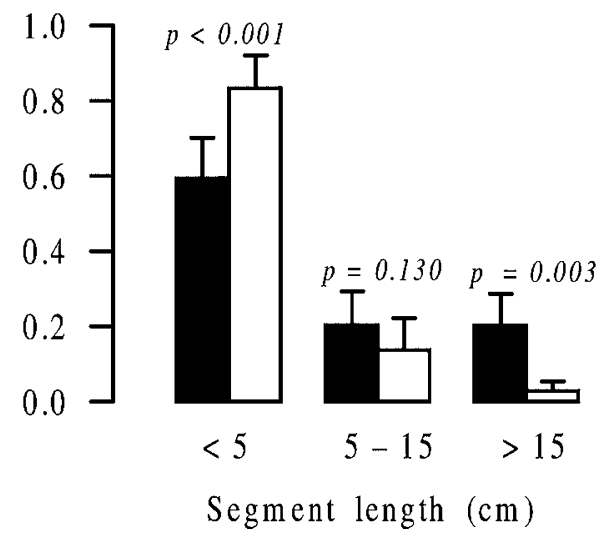

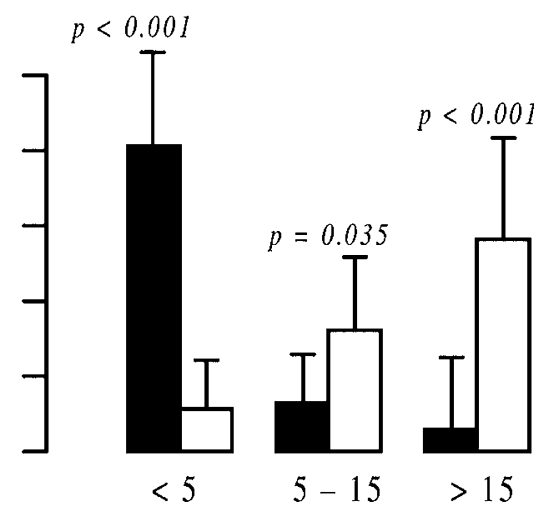

d.

1997

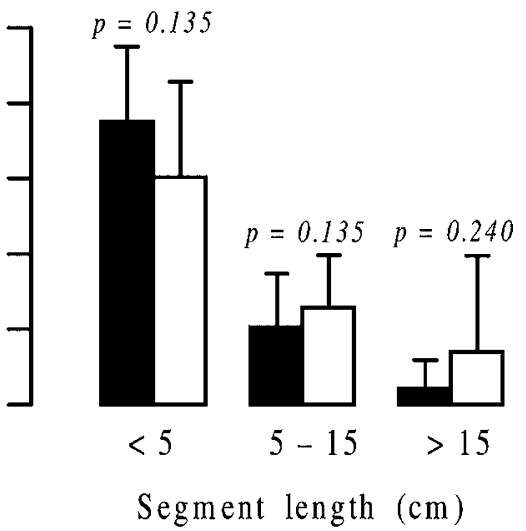

Figure 2. Comparisons of the proportion of segments in 3 length classes on willow stems located outside (browsed) and inside (protected) elk exclosures $(n=4)$ in Rocky Mountain National Park, Colorado. Exclosures were constructed in fall 1994 and stems were sampled in late August 1998; thus, year 1998 represents segments that had not been browsed by elk during the 1998/1999 winter season. Probability values were based on transformed data (see Methods section).

15 ANCOVAs (3 length classes $\times 5$ years). We did find a significant species effect $(P<0.001)$ for year 1998 , length class $>15 \mathrm{~cm}$; however, the effect was due to variation in magnitude among species rather than variation in direction (browsed length was greater than protected length in all species). Thus, segment length results are reported for combined species because we found little evidence that treatment effect depended on willow species.
How did segment length differ on browsed and protected stems? In 1994-1997, nearly $80 \%$ of segments on browsed stems were $<5 \mathrm{~cm}$ in length, with relatively few segments $>15$ $\mathrm{cm}$ in length (Figs. 2a-2d). There were a greater number of longer segments, especially segments $>15 \mathrm{~cm}$ in length, and fewer shorter segments on protected stems than on browsed stems in 1994-1996, but in 1997 these differences had disappeared (Fig. 2d). For segment year 1998, browsed stems 
had a higher proportion of segments $>15 \mathrm{~cm}$ in length than protected stems (Fig. 2e), likely because we removed stems before winter elk browsing reduced leader length and because there were fewer stems $<15 \mathrm{~cm}$ in length in 1998 than in previous years. More than $80 \%$ of segments on protected stems were $<5 \mathrm{~cm}$ in length in 1998 (Fig. 2e), whereas short segments comprised only about $10 \%$ of segments in the first 2 years after protection (Figs. $2 a$ and $2 b$ ). The mean height of entire stems before they were cut into segments was $2.2 \mathrm{~m}$ (standard deviation $[\mathrm{SD}]=0.2$ ) for protected stems and $1.3 \mathrm{~m}$ $(\mathrm{SD}=0.3)$ for browsed stems. These patterns suggest that stems responded to protection from elk browsing by growing much taller and increasing the production of short segments on tall stems as plants matured and became highly branched or bushy. Patterns for browsed stems showed proportional lengths were similar among years; however, length patterns were difficult to interpret on browsed stems because both elk browsing and plant growth affected segment length.

\section{DISCUSSION}

Retrospective measurements of stem segments made 4 years after cessation of winter elk browsing showed severely hedged willow stems produced longer stem segments that resulted in taller stems, which produced many more, but shorter segments as stems aged. These morphological changes greatly increased segment biomass of protected willows relative to stems that remained available to elk, especially during the first 3 years after protection. In contrast, stems outside elk exclosures accumulated a relatively small number of segments and segment biomass as winter browsing by elk removed current annual growth and maintained willow stems in a suppressed short-hedged $(<1.5 \mathrm{~m}$ tall $)$ morphological state. Thus, we found strong evidence that hedged willow stems were not in an alternative stable state but rather were highly resilient after release from intense elk browsing (treatment effect), despite the small sample size $(n=4)$ of this experiment. However, evidence for population estimates and estimates indicating lack of treatment effects due to willow species were weak because our design lacked replication at the within-plot scale.

\section{Effects of Browsing on Willow Stem Morphology}

How does browsing by elk or other large herbivores affect the morphology of willow stems? Browsing removes tissue from the tops of stems (leaders) and plants can respond by shunting carbon stores from roots to shoots (new growth) and by increasing leaf nitrogen, photosynthetic rate, growth rate, diameter near the bite, and branching (Danell et al. 1994; Hobbs 1996; Honkanen and Haukioja 1998; Strauss and Agrawal 1999). Willows can largely compensate for biomass lost to winter browsing by increasing productivity of browsedamaged stems (Wolff 1978; Hjalten 1999; Peinetti et al. 2001).

The stems of willows and many other plants contain both long and short shoots (Del Tredici 2001), which affects stem morphology and response to browsing (in this article, the term shoot includes only new growth, whereas the term segment includes any age cohort separated by nodes on stems). Short shoots lack lateral branches and are more prevalent on older stems that exhibit fourth- or fifth-order branching. The presence of numerous short shoots at the tips of mature, unbrowsed stems gives stems a full and soft appearance. Browsing frequency can be high on willows because regrowth rapidly becomes suitable as elk forage, although sexual reproduction can be eliminated and fitness can be reduced (Kay 1994; Gage and Copper 2005). Thus, repeated browsing can create productive but short-hedged plants with most or all leaders within reach of elk.

\section{Release of Willow Stems From Elk Browsing}

What mechanisms likely explain the patterns we observed when severely hedged willow stems were released from elk browsing? We found that protected stems had many more long segments $(>15 \mathrm{~cm})$ and many fewer short segments $(<5 \mathrm{~cm})$ than did browsed stems in 1994 and 1995 (Fig. 2), which suggests stems initially responded to cessation of browsing by elongating existing shoots. This pattern reversed in 1997 and 1998 when $>80 \%$ of segments were $<5 \mathrm{~cm}$ in length, which is consistent with the expected pattern of fewer long shoots and more short shoots on stems that exhibited fourth- and fifth-order branching. These segments were small enough $(<3 \mathrm{~mm}$ in diameter) to be entirely consumed by beaver (Baker and Cade 1995), which suggests released stems were suitable as beaver food after 4 years of protection from elk. Browsed stems were largely composed of short segments in all years, although 1998 had relatively more segments $>15 \mathrm{~cm}$ in length because we removed stems before winter elk browsing could remove current annual growth. We suggest caution in relating our segment length data to shoot morphology patterns because we did not attempt to distinguish between long and short shoots on stems; thus, our short stem segments may have been either morphologically short shoots or long shoots that had been browsed shorter by elk.

\section{Restoration and Management Implications}

Evidence from this study suggests that willows are highly resilient to cessation of browsing and managers can restore tall willow stems simply by protecting short-hedged stems from further herbivory. In a study in Oregon, removal of livestock with and without removal of wild ungulate browsing resulted in dramatic regrowth of existing willows in both cases, but continued ungulate browsing significantly suppressed recovery of willow height, crown area, crown volume, biomass, and sexual reproduction (Case and Kauffman 1997). The strong resilience of willow stems after release from intense herbivory suggests that some degraded riparian ecosystems have not reached alternative stable states (Beisner et al. 2003). Other degraded sites may not recover after release from browsing if they have lost critical willow establishment and survival processes, such as beaver dams that create bare moist soil and elevated water tables.

How can land managers recover tall willow communities and beaver-willow mutualisms in heavily browsed environments? Redistribution of herbivores in combination with reduced stocking rates or population control may be necessary to reduce willow use, which can remain high under a wide range of herbivore densities (Belsky et al. 1999; Zeigenfuss et al. 1999). Exclosure fencing or riparian pastures to protect 
willows from large herbivores must be large enough to meet management objectives. Ecological modeling of a RMNP willow community suggests elk exclosures along streams must be at least 4 ha in size to sustain a beaver colony comprising 6 individuals (H.R. Peinetti, unpublished data, 2005). In Moraine Park, RMNP, beaver colonized a series of 4 small elk exclosures $(30 \times 46 \mathrm{~m}) 5$ years after their construction and clear-cut tall willows from a single exclosure in each of 4 successive years, but could not be sustained by the exclosures alone (B.W. Baker, personal observation, 19992003). Herding livestock to protect riparian willows has been effective on western rangelands, so similar strategies (e.g., hazing) may have application for native ungulates in park settings. Predation risk also can reduce elk use of riparian areas. In Yellowstone National Park, Wyoming, a 70-year absence of wolves (Canis lupus) as apex predators coincided with a period of poor cottonwood (Populus spp.) recruitment, which suggests elk had lost their fear of browsing in riparian areas (Beschta 2003). After wolf reintroductions, areas with higher predation risk, such as those with low visibility or presence of escape barriers, had young cottonwoods that were taller and less browsed by elk (Ripple and Beschta 2003). Thus, recovery of tall willows in heavily browsed environments may require some difficult and controversial decisions.

In conclusion, we found willow stems were strongly resilient to release from intense elk browsing. Protected stems (inside elk exclosures) rapidly increased in biomass and length for several years and then increased number of short segments as stems aged-morphological changes which resulted in tall and vigorous stems after 4 years. Hedged stems that remained available to elk were productive but gained little biomass and height each year as winter browsing removed current annual growth. We suggest future research investigate the response of entire plants to release from browsing, including stem turnover rate relative to segment elongation rate.

\section{ACKNOWLEDGMENTS}

We thank Nicholas Bethenod, Maximilian Rouer, and Marcel Schrijvers for their valued field assistance. Reviews by Brian Cade, Evan Wolf, Linda Zeigenfuss, and 3 anonymous referees greatly improved the manuscript. Brian Cade, Phil Chapman, and Rudy King provided valuable statistical advice.

\section{LITERATURE CITED}

Alliende, M. C., And J. L. Harper. 1989. Demographic studies of a dioecious tree. I. Colonization, sex, and age structure of a population of Salix cinerea. Journal of Ecology 77:1029-1047.

Alstad, K. P., J. M. Welker, S. A. Williams, and M. J. Trlica. 1999. Carbon and water relations of Salix monticola in response to winter browsing and changes in surface water hydrology: an isotopic study using ${ }^{13} \mathrm{C}$ and ${ }^{18} \mathrm{O}$. Oecologia 120:375-385.

BAKER, B. W. 2003. Beaver (Castor canadensis) in heavily browsed environments. Lutra 46:173-181.

Baker, B. W., and B. S. Cade. 1995. Predicting biomass of beaver food from willow stem diameters. Journal of Range Management 48:322-326.

Baker, B. W., H. C. Ducharme, D. C. S. Mitchell, T. R. Stanley, and H. R. Peinetti. 2005. Interaction of beaver and elk herbivory reduces standing crop of willow. Ecological Applications 15:110-118.

BakeR, B. W., and E. P. Hill. 2003. Beaver (Castor canadensis). In: G. A.
Feldhamer, B. C. Thompson, and J. A. Chapman [EDs.]. Wild mammals of North America: Biology, management, and conservation. 2nd ed. Baltimore, MD: Johns Hopkins University Press. p 288-310.

Baker, B. W., D. C. S. Mitchell, H. C. Ducharme, T. R. Stanley, and H. R. Peinetti. 2004. Why aren't there more beaver in Rocky Mountain National Park? Proceedings of the Colorado Riparian Association 17th Annual Conference; 13-15 October 2004; Estes Park, CO. Boulder, CO: Colorado Riparian Association. p 85-90.

Beisner, B. E., D. T. Haydon, and K. Cuddington. 2003. Alternative stable states in ecology. Frontiers in Ecology and the Environment 1:376-382.

Belsky, A. J., A. Matzke, and S. Uselman. 1999. Survey of livestock influences on stream and riparian ecosystems in the western United States. Journal of Soil and Water Conservation 54:419-431.

BesCHTA, R. L. 2003. Cottonwoods, elk, and wolves in the Lamar Valley of Yellowstone National Park. Ecological Applications 13:1295-1309.

Brookshire, E. N. J., J. B. Kauffman, D. Lytjen, and N. Otting. 2002. Cumulative effects of wild ungulate and livestock herbivory on riparian willows. Oecologia 132:559-566.

Case, R. L., And J. B. Kauffman. 1997. Wild ungulate influences on the recovery of willows, black cottonwood, and thin-leaf alder following cessation of cattle grazing in Northeastern Oregon. Northwest Science 71:115-126.

DAHL, B. E. 1995. Developmental morphology of plants. In: D. J. Bedunah and R. E. Sosebee [EDS.]. Wildland Plants: Physiological ecology and developmental morphology. Denver, C0: Society for Range Management. p 22-58.

DanelL, K., R. Bergstrom, and L. Edenius. 1994. Effects of large mammalian browsers on architecture, biomass, and nutrients of woody plants. Journal of Mammalogy 75:833-844.

DeL TredicI, P. 2001. Sprouting in temperate trees: a morphological and ecological review. The Botanical Review 67:121-140.

GaGe, E. A., and D. J. Cooper. 2005. Patterns of willow seed dispersal, seed entrapment and seedling establishment in a heavily browsed montane riparian ecosystem. Canadian Journal of Botany 83:678-687.

HJALTEN, J. 1999. Willow response to pruning: effect on plant growth, survival and susceptibility to leaf gallers. Ecoscience 6:62-67.

HoBBs, N. T. 1996. Modification of ecosystems by ungulates. Journal of Wildlife Management 60:695-713.

Honkanen, T., and E. Haukioja. 1998. Intra-plant regulation of growth and plantherbivore interactions. Ecoscience 5:470-479.

KaY, C. E. 1994. The impact of native ungulates and beaver on riparian communities in the Intermountain West. Natural Resource and Environmental Issues 1:23-44.

KindsCHY, R. R. 1985. Response of red willow to beaver use in southeastern Oregon. Journal of Wildlife Management 49:26-28.

KINDSCHY, R. R. 1989. Regrowth of willow following simulated beaver cutting. Wildlife Society Bulletin 17:290-294.

Laundre, J. W., L. Hernandez, and K. B. Altendorf. 2001. Wolves, elk, and bison: reestablishing the "landscape of fear" in Yellowstone National Park, U.S.A. Canadian Journal of Zoology 79:1401-1409.

Laycock, W. A. 1991. Stable states and thresholds of range condition on North American rangelands: a viewpoint. Journal of Range Management 44: 427-432.

Lubow, B. C., F. J. Singer, T. L. Johnson, And D. C. Bowden. 2002. Dynamics of interacting elk populations within and adjacent to Rocky Mountain National Park. Journal of Wildlife Management 66:757-775.

Menezes, R. S. C., E. T. Elliott, D. W. Valentine, and S. A. Williams. 2001. Carbon and nitrogen dynamics in elk winter ranges. Journal of Range Management $66: 400-408$

Peinetti, H. R., M. A. Kalkhan, and M. B. Coughenour. 2002. Long-term changes in willow spatial distribution on the elk winter range of Rocky Mountain National Park (USA). Landscape Ecology 17:341-354.

Peinetti, H. R., R. S. C. Menezes, and M. B. Coughenour. 2001. Changes induced by elk browsing in the aboveground biomass production and distribution of willow (Salix monticola Bebb): their relationships with plant water, carbon, and nitrogen dynamics. Oecologia 127:334-342.

RIPPLE, W. J., AND R. L. BESCHTA. 2003. Wolf reintroduction, predation risk, and 
cottonwood recovery in Yellowstone National Park. Forest Ecology and Management 184:299-313.

Ripple, W. J., AND R. L. BeschtA. 2004. Wolves and the ecology of fear: can predation risk structure ecosystems? BioScience 54:755-766.

SAS Institute. 2000. SAS/STAT user's guide, version 8. Cary, NC: SAS Institute, Inc.

Singer, F. J., L. C. Zeigenfuss, R. G. CATES, And D. T. BARnett. 1998. Elk, multiple factors, and persistence of willows in national parks. Wildlife Society Bulletin 26:419-428.

Singer, F. J., L. C. Zeigenfuss, B. C. Lubow, And M. J. Rock. 2002. Ecological evaluation of potential overabundance of ungulates in U.S. National Parks: a case study. In: F. J. Singer and L. C. Zeigenfuss [comps.]. Ecological evaluation of the abundance and effects of elk herbivory in Rocky Mountain National Park, Colorado 1994-1999. Final Report to the National Park Service, Rocky Mountain National Park. Fort Collins, CO: USGS-FORT. Open File Report 02-208. p 205-248.
Strauss, S. Y., and A. A. Agrawal. 1999. The ecology and evolution of plant tolerance to herbivory. Trends in Ecology and Evolution 14:179-185.

Suding, K. N., K. L. Gross, and G. R. Houseman. 2004. Alternative states and positive feedbacks in restoration ecology. Trends in Ecology and Evolution 19:46-53.

WoLfF, J. 0. 1978. Burning and browsing effects on willow growth in interior Alaska. Journal of Wildlife Management 42:135-140.

Zeigenfuss, L. C., F. J. Singer, And D. Bowden. 1999. Vegetation responses to natural regulation of elk in Rocky Mountain National Park. Springfield, VA: Department of Interior, U.S. Geological Survey, National Technical Information Service. Biological Science Report USGS/BRD/BSR-1999-0003. 23 p.

Zeigenfuss, L. C., F. J. SingeR, S. A. Williams, and T. L. Johnson. 2002. Influences of herbivory and water on willow in elk winter range. Journal of Wildlife Management 66:788-795. 